\title{
ANALISIS KINERJA LALU LiNTAS AKIBAT PEMBANGUNAN Pelabuhan Taddan di Kabupaten SAMPang
}

\author{
Sabila Rosadi ${ }^{1)}$, Zainal Abidin'2), Miftachul Huda ${ }^{3)}$ \\ 1), 2), 3)Teknik Sipil, Teknik, Universitas Muhammadiyah Surabaya \\ Jl.Sutorejo No 59, 60113 \\ Email: miftachulhuda@,ft.um-surabaya.ac.id
}

\begin{abstract}
Taddan Port is a new port in Sampang Madura district which is expected to be the center of new activities planned to be operational in 2018, so that traffic performance is needed before and after the Taddan port operation. This study aims to determine the performance of existing traffic before and after the Taddan port operation in unsignalized intersections and interurban road around the Taddan port location and it recommendation. This study was analyzed using the Indonesian Road Capacity Manual (MKJI) with KAJI and Excel software. The primary data in this study are survey peak hour in active day and passive day, geometric survey of road and unsignalized intersections, and environmental conditions while secondary data are population numbers, vehicle growth, location maps, width of Tanglok Port (old) and width of Taddan Port (new). The results of the analysis of the existing traffic performance (2018) with the KAJI and Excel software show that the degree of saturation (DS) of the unsignalized intersection Jl. Mutiara - Jl. Diponegoro, Jl. Prajjan - Jl. Camplong and interurban road Jl. Taddan in the existing conditions are $0.74,0.73$ and 0.65 . While the degree of saturation (DS) in the year (2018) with software KAJI and Excel after the Taddan port operation are $0.86,0.84$ and 0.75 .
\end{abstract}

Keywords: degree of saturation (DS), MKJI, unsignalized, interurban, port

\begin{abstract}
Abstrak
Pelabuhan Taddan adalah pelabuhan baru di kabupaten Sampang Madura yang diperkirakan akan menjadi pusat aktifitas baru yang direncanakan akan beroperasi pada tahun 2018, sehingga perlu diketahui kinerja lalu lintas sebelum dan sesudah pelabuhan Taddan beroperasi. Penelitian ini bertujuan untuk mengetahui kinerja lalu lintas eksisting sebelum dan setelah pelabuhan Taddan beroperasi pada simpang tak bersinyal dan ruas jalan di sekitar lokasi pelabuhan Taddan serta merekomendasikannya. Penelitian ini dianalisis menggunnakan Manual Kapasitas Jalan Indonesia (MKJI) dengan software KAJI dan Excel. Data primer pada penelitian ini adalah survei lalu lintas jam puncak hari aktif dan hari libur, survei geometrik ruas jalan dan simpang tak bersinyal, dan kondisi lingkungan sedangkan data sekunder adalah jumlah penduduk, jumlah pertumbuhan kendaraan, peta lokasi, luas Pelabuhan Tanglok (lama) dan luas rencana Pelabuhan Taddan (baru). Hasil analisis kinerja lalu lintas eksisting (2018) dengan software KAJI dan Excel menunjukkan bahwa nilai derajat kejenuhan simpang tak bersinyal J1. Mutiara - J1. Diponegoro, Jl. Prajjan - Jl. Camplong dan ruas jalan antar kota Jl.Taddan pada kondisi eksisting memiliki nilai $0.74,0.73$, dan 0.65 . Sedangkan nilai derajat kejenuhan pada tahun (2018) dengan software KAJI dan Excel setelah pelabuhan Taddan beroperasi memiliki nilai 0.86, 0.84, dan 0.75 .
\end{abstract}

Kata Kunci: derajat kejenuhan (DS), MKJI, tak bersinyal, antar kota, pelabuhan

\section{PENDAHULUAN}

Lokasi di mana aktivitas dilakukan akan mempengaruhi manusia, barang dan jasa, yang akan mempengaruhi lokasi tempat aktivitas berlangsung. (Khisty dan Lall dalam Huda, 2016)

Pelabuhan merupakan salah satu pusat terjadinya perjalanan selain pusat perdagangan, permukiman, gedung perkantoran, sekolah, pasar tradisional/modern, dan lainlain. (Huda, 2016)

Menurut Huda (2017) tata guna lahan merupakan salah satu dari penentu utama pergerakan dan aktivitas. Huda (2016) menyatakan jenis tata guna lahan yang berbeda mempunyai ciri lalu lintas yang berbeda seperti jumlah arus lalu lintas, jenis arus lalu lintas maupun waktu arus lalu lintas.

Pelabuhan Taddan berada di desa Taddan, kecamatan Camplong, kabupaten Sampang terletak sekitar tujuh kilometer sebelah timur kota Sampang yang terhubung dengan jalan provinsi dan termasuk pelabuhan umum yang melayanai angkutan penumpang dan barang berskala provinsi Taddan yamg melayani kapal besar serta dermaga penyebrangan kapal Fery, dengan rute Sampang -
Pulau Mandangin - Probolinggo - Pasuruan - Situbondo dan sektarnya.

Pelabuhan Taddan dibangun disebabkan oleh pelabuhan Tanglok yang jadwal dan trayeknya belum teratur karena terkendala kondisi geografis yang kurang memadai. Trayek tetap dan teratur dalah pelayanan angkutan yang dilakukan dalam jaringan trayek secara tetap dan teratur, dengan jadwal tetap atau tidak terjadwal. (Abidin, 2016)

Pelabuhan Taddan saat ini masih dalam tahap pembangunan. Aktivitas pembangunan dan pelabuhan Taddan saat beroperasi akan memberi pengaruh langsung terhadap arus lalu lintas di sekitarnya. Menurut Hoobs dalam Huda (2016) arus atau aliran adalah jumlah kendaraan yang terdapat dalam suatu ruang yang diukur dalam suatu interval tertentu.

\section{Rumusan Masalah}

- Bagaimana kinerja lalu lintas eksisting di beberapa ruas jalan dan simpang di sekitar lokasi studi?

- Bagaimana memprediksi besarnya bangkitan dan tarikan perjalanan, dan pembebanan lalu lintas kendaraan akibat pembangunan Pelabuhan Taddan? 
- Bagaimana kinerja lalu lintas di beberapa ruas jalan dan simpang di sekitar lokasi studi pada tahun 2018/2019 saat Pelabuhan Taddan mulai beroperasi?

\section{METODE PENELITIAN}

\section{Diagram Alir}

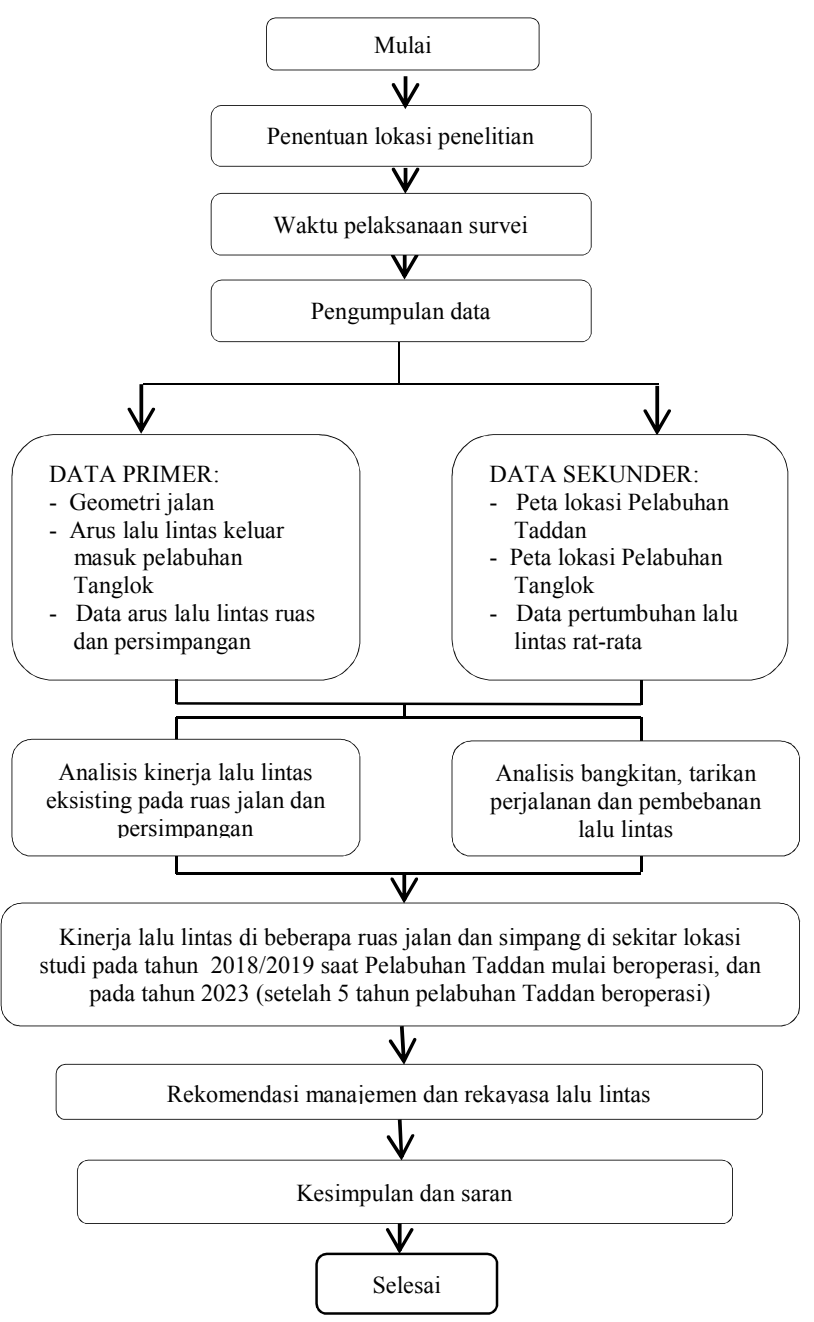

\section{Lokasi Pengambilan Data}

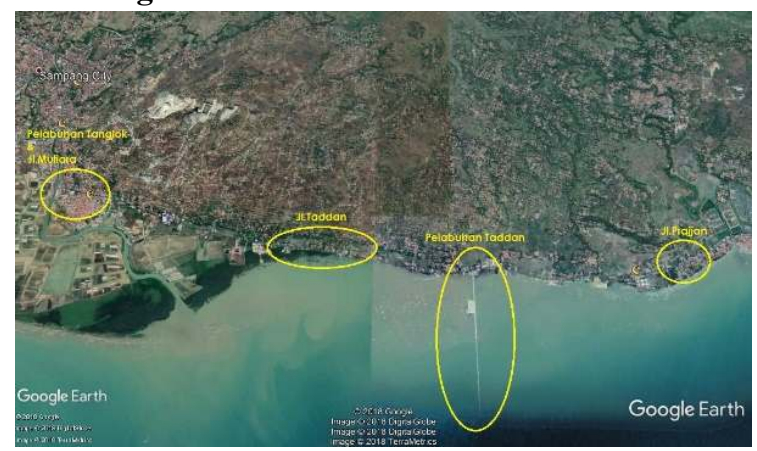

Gambar 1 Lokasi pengambilan data Sumber: Google Earth 2018

\section{Waktu Pelaksanaan}

Pengambilan data dilakukan pada hari efektif (Rabu dan Kamis), tanggal 3 - 4 Januari 2018, dan akhir pekan (Sabtu dan Minggu), tanggal 6 - 7 Januari 2018. Waktu survei dilakukan pada pukul 06.00 - 08.00 WIB, 11.00 - 13.00 WIB dan 15.00 - 17.00 WIB.

\section{Metode Analisis}

Metode analisis menggunakan Manual Kapasitas Jalan Indonesia (MKJI) tahun 1995, dengan alat batu KAJI dan Excel.

\section{Pengumpulan Data}

- Data primer

a. Geometri jalan

b. Arus lalu lintas pada jam puncak (LV, HV dan MC)

c. Data arus lalu lintas keluar masuk pelabuhan lama

d. Kondisi lingkungan

\section{- Data sekunder}
a. Peta lokasi Pelabuhan Taddan (baru) dengan luasannya.
b. Peta lokasi Pelabuhan Tanglok (lama) dengan luasannya.
c. Jumlah penduduk di kabupaten Sampang

\section{HASIL PENELITIAN DAN PEMBAHASAN Hasil Pengumpulan Data Eksisting Geometrik}

1. Simpang Jl. Mutiara - J1. Diponegoro

Tabel 1 Geometrik simpang Jl. Mutiara - Jl. Diponegoro

\begin{tabular}{cccc}
\hline Pendekat & Jumlah lajur & Pendekat masuk (m) & Lebar jalan $(\mathrm{m})$ \\
\hline Barat & 2 & 3 & 6 \\
\hline Utara & 2 & 2 & 4 \\
\hline Timur & 2 & 3 & 6 \\
\hline
\end{tabular}

Sumber: Rekapitulasi Hasil survei (2018)

2. Simpang Jl. Prajjan - Jl. Raya Camplong

Tabel 2 Geometrik simpang Jl. Prajjan - Jl. Raya Camplong

\begin{tabular}{cccc}
\hline Pendekat & Jumlah lajur & Pendekat masuk $(\mathrm{m})$ & Lebar jalan $(\mathrm{m})$ \\
\hline Barat & 2 & 3 & 6 \\
\hline Utara & 2 & 2 & 4 \\
\hline Timur & 2 & 3 & 6 \\
\hline
\end{tabular}

Sumber: Rekapitulasi Hasil survei (2018)

3. Ruas Jl. Tadaan

Tabel 3 Geometrik ruas J1. Taddan

\begin{tabular}{ccccc}
\hline Pendekat & Jumlah lajur & Lebar Lajur $(\mathrm{m})$ & $\begin{array}{c}\text { Lebar Jalan } \\
(\mathrm{m})\end{array}$ & $\begin{array}{c}\text { Lebar bahu } \\
(\mathrm{m})\end{array}$ \\
\hline Barat & 2 & 3 & 6 & 2 \\
\hline Timur & 2 & 3 & 6 & 2 \\
\hline
\end{tabular}

Sumber: Rekapitulasi Hasil survei (2018) 


\section{Volume lalu lintas eksisting}

1. Volume kend/jam

a. Simpang Jl. Mutiara - Jl. Diponegoro

Tabel 4 Volume kend/jam jam puncak pagi simpang $\mathrm{Jl}$. Mutiara - Jl. Diponegoro hari aktif (Rabu dan Kamis)

\begin{tabular}{|c|c|c|c|c|c|c|c|}
\hline \multirow{2}{*}{ Hari } & \multirow{2}{*}{ Pendekat } & \multirow{2}{*}{ Arah } & \multicolumn{3}{|c|}{ Kend/jam } & \multirow{2}{*}{ Total per-arah } & \multirow{2}{*}{ Total } \\
\hline & & & $\mathrm{LV}$ & $\mathrm{HV}$ & $\mathrm{MC}$ & & \\
\hline \multirow{6}{*}{ Rabu } & \multirow{2}{*}{ Barat } & $\mathrm{LT}$ & 9 & 0 & 64 & 73 & \multirow{6}{*}{2415} \\
\hline & & ST & 342 & 52 & 571 & 965 & \\
\hline & \multirow{2}{*}{ Utara } & LT & 32 & 0 & 70 & 102 & \\
\hline & & RT & 32 & 1 & 76 & 109 & \\
\hline & \multirow{2}{*}{ Timur } & RT & 30 & 0 & 70 & 100 & \\
\hline & & ST & 386 & 63 & 617 & 1066 & \\
\hline \multirow{6}{*}{ Kamis } & \multirow{2}{*}{ Barat } & LT & 8 & 1 & 65 & 74 & \multirow{6}{*}{2195} \\
\hline & & ST & 271 & 39 & 541 & 851 & \\
\hline & \multirow{2}{*}{ Utara } & LT & 5 & 1 & 83 & 89 & \\
\hline & & RT & 17 & 1 & 83 & 101 & \\
\hline & \multirow{2}{*}{ Timur } & RT & 18 & 0 & 68 & 86 & \\
\hline & & ST & 325 & 42 & 627 & 994 & \\
\hline
\end{tabular}

Sumber: Rekapitulasi Hasil survei (2018)

Tabel 5 Volume kend/jam jam puncak pagi simpang Jl.mutiara - Jl. Diponegoro hari libur (Sabtu dan Minggu)

\begin{tabular}{|c|c|c|c|c|c|c|c|}
\hline \multirow{2}{*}{ Hari } & \multirow{2}{*}{ Pendekat } & \multirow{2}{*}{ Arah } & \multicolumn{3}{|c|}{ Kend/jam } & \multirow{2}{*}{$\begin{array}{l}\text { Total per- } \\
\text { arah }\end{array}$} & \multirow{2}{*}{ Total } \\
\hline & & & LV & $\mathrm{HV}$ & $\mathrm{MC}$ & & \\
\hline \multirow{6}{*}{ Sabtu } & \multirow{2}{*}{ Barat } & LT & 4 & 0 & 74 & 78 & \multirow{6}{*}{2043} \\
\hline & & ST & 241 & 70 & 487 & 798 & \\
\hline & \multirow{2}{*}{ Utara } & $\mathrm{LT}$ & 11 & 2 & 71 & 84 & \\
\hline & & RT & 5 & 1 & 65 & 71 & \\
\hline & \multirow{2}{*}{ Timur } & RT & 5 & 0 & 48 & 53 & \\
\hline & & ST & 238 & 81 & 640 & 959 & \\
\hline \multirow{6}{*}{ Minggu } & \multirow{2}{*}{ Barat } & $\mathrm{LT}$ & 6 & 2 & 62 & 70 & \multirow{6}{*}{2050} \\
\hline & & ST & 246 & 43 & 578 & 867 & \\
\hline & \multirow{2}{*}{ Utara } & $\mathrm{LT}$ & 4 & 0 & 47 & 51 & \\
\hline & & RT & 6 & 1 & 67 & 74 & \\
\hline & \multirow{2}{*}{ Timur } & RT & 5 & 0 & 47 & 52 & \\
\hline & & ST & 279 & 43 & 614 & 936 & \\
\hline
\end{tabular}

Sumber: Rekapitulasi Hasil survei (2018)

b. Simpang Jl. Prajjan - Jl. Raya Camplong

Tabel 6 Volume kend/jam jam puncak pagi simpang Jl. Prajjan - Jl. Raya Camplong hari aktif (Rabu dan Kamis)

\begin{tabular}{|c|c|c|c|c|c|c|c|}
\hline \multirow{2}{*}{ Hari } & \multirow{2}{*}{ Pendekat } & \multirow{2}{*}{ Arah } & \multicolumn{3}{|c|}{ Kend/jam } & \multirow{2}{*}{$\begin{array}{l}\text { Total per- } \\
\text { arah }\end{array}$} & \multirow{2}{*}{ Tota } \\
\hline & & & LV & $\mathrm{HV}$ & $\mathrm{MC}$ & & \\
\hline \multirow{6}{*}{ Rabu } & \multirow{2}{*}{ Barat } & $\mathrm{LT}$ & 20 & 0 & 67 & 87 & \multirow{6}{*}{2414} \\
\hline & & ST & 412 & 51 & 599 & 1062 & \\
\hline & \multirow{2}{*}{ Utara } & LT & 32 & 2 & 57 & 91 & \\
\hline & & RT & 13 & 0 & 54 & 67 & \\
\hline & \multirow{2}{*}{ Timur } & $\overline{\mathrm{RT}}$ & 23 & 4 & 57 & 84 & \\
\hline & & ST & 434 & 64 & 525 & 1023 & \\
\hline \multirow{6}{*}{ Kamis } & \multirow{2}{*}{ Barat } & LT & 8 & 0 & 69 & 77 & \multirow{6}{*}{2168} \\
\hline & & ST & 266 & 51 & 616 & 933 & \\
\hline & \multirow{2}{*}{ Utara } & LT & 18 & 0 & 66 & 84 & \\
\hline & & RT & 14 & 1 & 66 & 81 & \\
\hline & \multirow{2}{*}{ Timur } & RT & 22 & 0 & 57 & 79 & \\
\hline & & ST & 283 & 50 & 581 & 914 & \\
\hline
\end{tabular}

Sumber: Rekapitulasi Hasil survei (2018)
Tabel 7 Volume kend/jam jam puncak pagi simpang Jl. Prajjan - Jl. Raya Camplong hari libur (Sabtu dan Minggu)

\begin{tabular}{|c|c|c|c|c|c|c|c|}
\hline \multirow{2}{*}{ Hari } & \multirow{2}{*}{ Pendekat } & \multirow{2}{*}{ Arah } & \multicolumn{3}{|c|}{ Kend/jam } & \multirow{2}{*}{$\begin{array}{l}\text { Total per- } \\
\text { arah }\end{array}$} & \multirow{2}{*}{ Total } \\
\hline & & & $\mathrm{LV}$ & $\mathrm{HV}$ & $\mathrm{MC}$ & & \\
\hline \multirow{6}{*}{ Sabtu } & \multirow{2}{*}{ Barat } & LT & 6 & 0 & 38 & 44 & \multirow{6}{*}{1911} \\
\hline & & ST & 264 & 80 & 508 & 852 & \\
\hline & \multirow{2}{*}{ Utara } & $\overline{L T}$ & 19 & 0 & 53 & 72 & \\
\hline & & RT & 8 & 2 & 45 & 55 & \\
\hline & \multirow{2}{*}{ Timur } & RT & 9 & 0 & 38 & 47 & \\
\hline & & ST & 264 & 71 & 506 & 841 & \\
\hline \multirow{6}{*}{ Minggu } & \multirow{2}{*}{ Barat } & LT & 14 & 5 & 64 & 83 & \multirow{6}{*}{2217} \\
\hline & & ST & 256 & 55 & 596 & 907 & \\
\hline & \multirow{2}{*}{ Utara } & LT & 30 & 1 & 60 & 91 & \\
\hline & & RT & 9 & 1 & 133 & 143 & \\
\hline & \multirow{2}{*}{ Timur } & RT & 18 & 1 & 64 & 83 & \\
\hline & & ST & 261 & 48 & 601 & 910 & \\
\hline
\end{tabular}

Sumber: Rekapitulasi Hasil survei (2018)

c. Ruas Jl. Taddan

Tabel 8 Volume kend/jam jam puncak pagi ruas Jl. Taddan hari aktif (Rabu dan Kamis)

\begin{tabular}{ccccccccc}
\hline \multirow{2}{*}{ Hari } & $\begin{array}{c}\text { Pende } \\
\text { kat }\end{array}$ & LV & MHV & LB & LT & MC & $\begin{array}{c}\text { Total } \\
\text { per- } \\
\text { arah }\end{array}$ & Total \\
\hline \multirow{2}{*}{ Rabu } & Barat & 365 & 46 & 10 & 19 & 625 & 1065 & 22272 \\
\cline { 2 - 8 } & Timur & 455 & 49 & 9 & 29 & 665 & 1207 & 2203 \\
\hline \multirow{2}{*}{$\begin{array}{c}\text { Kami } \\
\text { s }\end{array}$} & Barat & 297 & 29 & 4 & 20 & 595 & 945 & \multirow{2}{*}{1933} \\
\cline { 2 - 7 } & Timur & 326 & 30 & 10 & 22 & 610 & 988 & \\
\hline
\end{tabular}

Sumber: Rekapitulasi Hasil survei (2018)

Tabel 9 Volume kend/jam jam puncak pagi ruas Jl. Taddan hari libur (Sabtu dan Minggu)

\begin{tabular}{ccccccccc}
\hline \multirow{2}{*}{ Hari } & $\begin{array}{c}\text { Pende } \\
\text { kat }\end{array}$ & LV & MHV & LB & LT & MC & $\begin{array}{c}\text { Total } \\
\text { per- } \\
\text { arah }\end{array}$ & Total \\
\hline \multirow{2}{*}{ Sabtu } & Barat & 266 & 46 & 10 & 19 & 530 & 871 & \multirow{2}{*}{1716} \\
\cline { 2 - 8 } $\begin{array}{c}\text { Timur } \\
\text { gu }\end{array}$ & 266 & 49 & 9 & 29 & 492 & 845 & \\
\cline { 2 - 7 } & Barat & 247 & 37 & 6 & 22 & 650 & 962 & \multirow{2}{*}{1912} \\
\hline
\end{tabular}

Sumber: Rekapitulasi Hasil survei (2018)

\section{Bangkitan, tarikan perjalanan dan pembebanan lalu lintas}

Tabel 10 Prediksi volume bangkitan Pelabuhan Taddan (Baru) pada hari aktif (Rabu)

\begin{tabular}{ccc}
\hline $\begin{array}{c}\text { Nama } \\
\text { pelabuhan }\end{array}$ & $\begin{array}{c}\text { Luasan } \\
\text { dermaga }\left(\mathrm{m}^{2}\right)\end{array}$ & Bangkitan perjalanan \\
\hline Tanglok (Lama) & 300 & $82,1 \mathrm{smp} / \mathrm{jam}=0,274(\mathrm{smp} / \mathrm{jam}) \mathrm{m}^{2}$ \\
\hline Taddan (Baru) & 1000 & $274 \mathrm{smp} / \mathrm{jam}$ \\
\hline Sumber: Hasil pengolahan data &
\end{tabular}

Sumber: Hasil pengolahan data

Tabel 11 Prediksi volume bangkitan Pelabuhan Taddan (Baru) pada hari libur (Minggu)

\begin{tabular}{ccc}
\hline $\begin{array}{c}\text { Nama } \\
\text { pelabuhan }\end{array}$ & $\begin{array}{c}\text { Luasan } \\
\text { dermaga }\left(\mathrm{m}^{2}\right)\end{array}$ & Bangkitan perjalanan \\
\hline Tanglok (Lama) & 300 & $62,2 \mathrm{smp} / \mathrm{jam}=0,208(\mathrm{smp} / \mathrm{jam}) \mathrm{m}^{2}$ \\
\hline Taddan (Baru) & 1000 & $208 \mathrm{smp} / \mathrm{jam}$ \\
\hline Sumber: Hasil pengolahan data &
\end{tabular}


Tabel 12 Prediksi total volume bangkitan Pelabuhan Taddan (Baru) pada hari aktif (Rabu)

\begin{tabular}{ccccccc}
\hline Nama pelabuhan & \multicolumn{3}{c}{ Kendaraan masuk } & \multicolumn{3}{c}{ Kendaraan keluar } \\
\hline Tanglok (Lama) & LV & HV & MC & LV & HV & MC \\
\hline Persentase & 21,8 & 5,6 & 72,6 & 21 & 6,6 & 72,4 \\
\hline Taddan (Baru) & 60 & 12 & 398 & 57 & 14 & 397 \\
\hline
\end{tabular}

Sumber: Hasil pengolahan data

Tabel 13 Prediksi total volume bangkitan Pelabuhan Taddan (Baru) pada hari libur (Minggu)

\begin{tabular}{ccccccc}
\hline Nama pelabuhan & \multicolumn{3}{c}{ Kendaraan masuk } & \multicolumn{3}{c}{ Kendaraan keluar } \\
\hline Tanglok (Lama) & LV & HV & MC & LV & HV & MC \\
\hline Persentase & 19,7 & 2,1 & 78,2 & 18,7 & 2 & 79,3 \\
\hline Taddan (Baru) & 41 & 3 & 325 & 39 & 3 & 330 \\
\hline
\end{tabular}

Sumber: Hasil pengolahan data

Tabel 14 Pembebanan kendaraan masuk Pelabuhan Taddan pada hari aktif (Rabu)

\begin{tabular}{cccccc}
\hline Lokasi & Pendekat & Jenis & Kend/jam & Pesentase & Tambah \\
\hline Simpang & Barat-Timur & LV & 342 & 0,41 & 25 \\
\cline { 2 - 6 } Jl.Mutiara & Utara-Timur & LV & 32 & 0,03 & 2 \\
\hline Simpang & Utara-Barat & LV & 13 & 0,01 & 1 \\
\cline { 2 - 6 } Jl.Prajjan & Timur-Barat & LV & 434 & 0,52 & 32 \\
\hline Total & & & 821 & 1 & 60 \\
\hline Simpang & Barat-Timur & HV & 52 & 0,44 & 5 \\
\cline { 2 - 6 } Jl.Mutiara & Utara-Timur & HV & 0 & 0 & 0 \\
\hline Simpang & Utara-Barat & HV & 0 & 0 & 0 \\
\cline { 2 - 6 } Jl.Prajjan & Timur-Barat & HV & 64 & 0,55 & 7 \\
\hline Total & & & 116 & 1 & 12 \\
\hline Simpang & Barat-Timur & MC & 571 & 0,46 & 186 \\
\cline { 2 - 6 } Jl.Mutiara & Utara-Timur & MC & 70 & 0,05 & 23 \\
\hline Simpang & Utara-Barat & MC & 54 & 0,04 & 18 \\
\cline { 2 - 6 } Jl.Prajjan & Timur-Barat & MC & 525 & 0,43 & 171 \\
\hline Total & & & 1220 & 1 & 398 \\
\hline
\end{tabular}

Sumber: Hasil pengolahan data

Tabel 15 Pembebanan kendaraan masuk Pelabuhan Taddan pada hari libur (Minggu)

\begin{tabular}{cccccc}
\hline Lokasi & Pendekat & Jenis & Kend/jam & Pesentase & Tambah \\
\hline Simpang & Barat-Timur & LV & 246 & 0,47 & 19 \\
\cline { 2 - 6 } Jl.Mutiara & Utara-Timur & LV & 4 & 0.007 & 0 \\
\hline Simpang & Utara-Barat & LV & 9 & 0,01 & 1 \\
\cline { 2 - 6 } Jl.Prajjan & Timur-Barat & LV & 261 & 0,50 & 20 \\
\hline Total & & & 520 & 1 & 41 \\
\hline Simpang & Barat-Timur & HV & 43 & 0,46 & 1,6 \\
\cline { 2 - 6 } Jl.Mutiara & Utara-Timur & HV & 0 & 0 & 0 \\
\hline Simpang & Utara-Barat & HV & 1 & 0,01 & 0 \\
\cline { 2 - 6 } Jl.Prajjan & Timur-Barat & HV & 48 & 0,52 & 1,8 \\
\hline Total & & & 92 & 1 & 3 \\
\hline Simpang & Barat-Timur & MC & 578 & 0,42 & 138 \\
\cline { 2 - 6 } Jl.Mutiara & Utara-Timur & MC & 47 & 0,03 & 11 \\
\hline Simpang & Utara-Barat & MC & 133 & 0,09 & 32 \\
\cline { 2 - 6 } Jl.Prajjan & Timur-Barat & MC & 601 & 0,44 & 144 \\
\hline Total & & & 1359 & 1 & 325
\end{tabular}

Sumber: Hasil pengolahan data

\section{Analisis kinerja lalu lintas eksisting}

1. Simpang J1. Mutiara - Jl. Diponegoro

a. Jam puncak simpang Jl. Mutiara - Jl. Diponegoro pada hari aktif dan hari libur

Berdasarkan analisis program Excel dan KAJI di bawah (Tabel 16 dan Gambar 2) mununjukan bahwa nilai derajat kejenuhan (DS) simpang tak bersinyal Jl. Mutiara Jl. Diponegoro pada tahun 2018 (eksisting) pada hari aktif (Rabu) adalah 0.74 (Excel) dan 0.736 (KAJI) yang berarti memiliki kinerja lalu lintas yang cukup baik.
Tabel 16 Jam puncak pagi simpang Jl. Mutiara - Jl.

\begin{tabular}{|c|c|c|c|c|c|c|c|}
\hline & & & рас & ra a & ( $\mathrm{T})$ & & \\
\hline $\begin{array}{c}\text { Arus } \\
\text { lalu } \\
\text { lintas } \\
\text { (Q) } \\
\text { smp/ja } \\
\mathrm{m}\end{array}$ & $\begin{array}{l}\text { Derajat } \\
\text { Kejenuh } \\
\text { an (DS) }\end{array}$ & $\begin{array}{c}\text { Tund } \\
\text { aan } \\
\text { lalu } \\
\text { lintas } \\
\text { Simp } \\
\text { ang } \\
\end{array}$ & $\begin{array}{c}\text { Tundaa } \\
n \\
\text { lalu } \\
\text { lintas } \\
\text { Jl.Utam } \\
\left.\text { a (DT }{ }_{1}\right) \\
\end{array}$ & $\begin{array}{c}\text { Tundaa } \\
\mathrm{n} \\
\text { lalu } \\
\text { lintas } \\
\text { J.l.Mino } \\
\mathrm{r}\left(\mathrm{D}_{\mathrm{MII}}\right)\end{array}$ & $\begin{array}{l}\text { Tund } \\
\text { aan } \\
\text { geom } \\
\text { etrik } \\
\text { simp } \\
\text { ang }\end{array}$ & $\begin{array}{l}\text { Tunda } \\
\text { an } \\
\text { Simpa } \\
\text { ng (D) }\end{array}$ & $\begin{array}{l}\text { Peluang } \\
\text { Antrian } \\
\text { (QP\%) }\end{array}$ \\
\hline $\begin{array}{l}1716 \\
\end{array}$ & 0.74 & 8.03 & 5.95 & 32 & 3.85 & 11.89 & 44.81 \\
\hline
\end{tabular}

Sumber: Hasil survei 2018

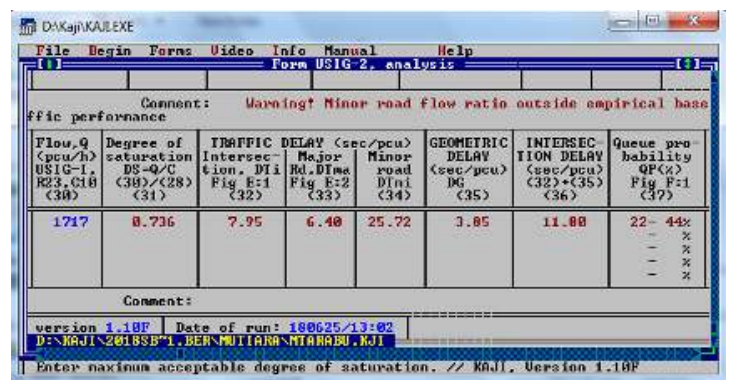

Gambar 2 Hasil kinerja eksisting simpang Jl. Mutiara - Jl. Diponegoro pada hari aktif (Rabu)

Sumber: Hasil survei 2018

Sedangkan pada hari libur (Minggu), berdasarkan analisis program Excel dan KAJI di bawah (Tabel 17 dan Gambar 3) mununjukan bahwa nilai derajat kejenuhan (DS) simpang tak bersinyal Jl. Mutiara - Jl. Diponegoro pada tahun 2018 (eksisting) adalah 0.60 (Excel) dan 0.572 (KAJI) yang berarti memiliki kinerja lalu lintas yang baik.

Tabel 17 Jam puncak pagi simpang Jl. Mutiara - Jl.

\begin{tabular}{|c|c|c|c|c|c|c|c|}
\hline \multirow{4}{*}{$\begin{array}{c}\text { Arus } \\
\text { lalu } \\
\text { lintas }\end{array}$} & \multicolumn{7}{|c|}{ Diponegoro pada hari libur (Minggu) } \\
\hline & & & & & & & \\
\hline & & aan & n & n & aan & an & \\
\hline & Kejenuh & lalu & lalu & lalu & geom & Simpa & Antrian \\
\hline (Q) & an (DS) & lintas & lintas & lintas & etrik & $\operatorname{ng}(\mathrm{D})$ & (QP\%) \\
\hline $\mathrm{smp} / \mathrm{ja}$ & & Simp & Jl.Utam & Jl.Mino & simp & & \\
\hline $\mathrm{m}$ & & ang & $\mathrm{a}\left(\mathrm{DT}_{1}\right)$ & $\mathrm{r}\left(\mathrm{D}_{\mathrm{Mll}}\right)$ & ang & & \\
\hline 1369 & 0.60 & 6.12 & 4.57 & 36 & 3.72 & 9.84 & 31.94 \\
\hline
\end{tabular}

Sumber: Hasil survei 2018

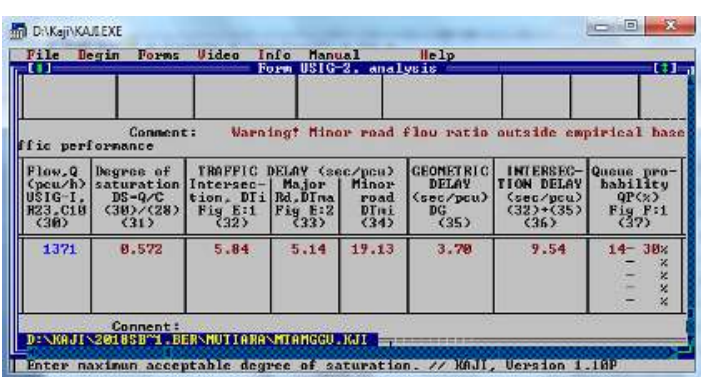

Gambar 3 Hasil kinerja eksisting simpang Jl. Mutiara - Jl. Diponegoro pada hari libur (Minggu) Sumber: Hasil survei 2018

2. Simpang J1. Prajjan - J1. Raya Camplong

a. Jam puncak simpang Jl. Prajjan - Jl. Raya Camplong pada hari aktif dan hari libur 
Berdasarkan analisis program Excel dan KAJI di bawah (Tabel 18 dan Gambar 4) mununjukan bahwa nilai derajat kejenuhan (DS) simpang tak bersinyal Jl. Prajjan Jl. Raya Camplong pada tahun 2018 (eksisting) pada hari aktif (Rabu) adalah 0.73 (Excel) dan 0.724 (KAJI) yang berarti memiliki kinerja lalu lintas yang cukup baik.

Tabel 18 Jam puncak pagi simpang Jl. Prajjan - Jl. Raya Camplong pada hari aktif (Rabu)

\begin{tabular}{|c|c|c|c|c|c|c|c|}
\hline $\begin{array}{c}\text { Arus } \\
\text { lalu } \\
\text { lintas } \\
\\
(\mathrm{Q}) \\
\text { smp/ja } \\
\text { m } \\
\end{array}$ & $\begin{array}{c}\text { Derajat } \\
\text { Kejenuh } \\
\text { an (DS) }\end{array}$ & $\begin{array}{c}\text { Tund } \\
\text { aan } \\
\text { lalu } \\
\text { lintas } \\
\text { Simp } \\
\text { ang }\end{array}$ & $\begin{array}{c}\text { Tundaa } \\
n \\
\text { lalu } \\
\text { lintas } \\
\text { Jl.Utam } \\
\text { a }\left(\mathrm{DT}_{1}\right) \\
\end{array}$ & $\begin{array}{c}\text { Tundaa } \\
\text { n } \\
\text { lalu } \\
\text { lintas } \\
\text { Jl.Mino } \\
\mathrm{r} \text { (D DI) }\end{array}$ & $\begin{array}{l}\text { Tund } \\
\text { aan } \\
\text { geom } \\
\text { etrik } \\
\text { simp } \\
\text { ang }\end{array}$ & $\begin{array}{c}\text { Tunda } \\
\text { an } \\
\text { Simpa } \\
\text { ng (D) }\end{array}$ & $\begin{array}{c}\text { Peluang } \\
\text { Antrian } \\
(\mathrm{QP} \%)\end{array}$ \\
\hline 1771 & 0.73 & 7.84 & 5.82 & 41 & 3.83 & 11.67 & \begin{tabular}{|l|}
33.58 \\
21.64
\end{tabular} \\
\hline
\end{tabular}

Sumber: Hasil survei 2018

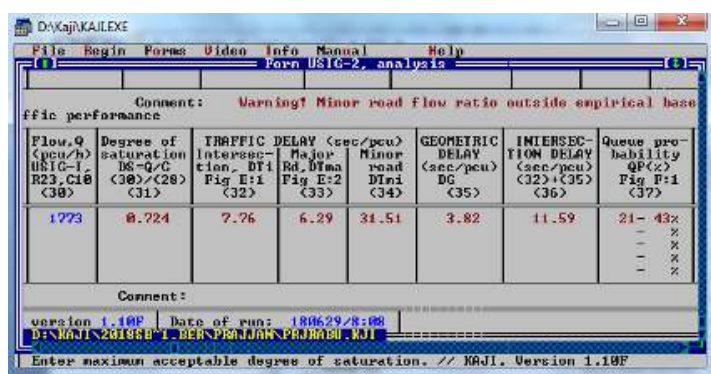

Gambar 4 Hasil kinerja eksisting simpang Jl. Prajjan - Jl. Raya Camplong pada hari aktif (Rabu) Sumber: Hasil survei 2018

Sedangkan pada hari libur (Minggu), berdasarkan analisis program Excel dan KAJI di bawah (Tabel 19 dan Gambar 5) mununjukan bahwa nilai derajat kejenuhan (DS) simpang tak bersinyal Jl. Prajjan - Jl. Raya Camplong pada tahun 2018 (eksisting) adalah 0.64 (Excel) dan 0.632 (KAJI) yang berarti memiliki kinerja lalu lintas yang baik.

Tabel 19 Jam puncak pagi simpang Jl. Prajjan - Jl. Raya Camplong pada hari libur (Minggu)

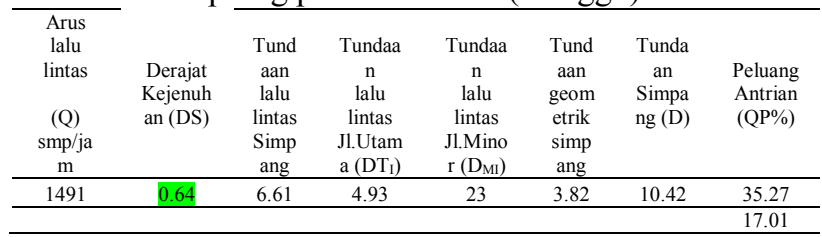

Sumber: Hasil survei 2018

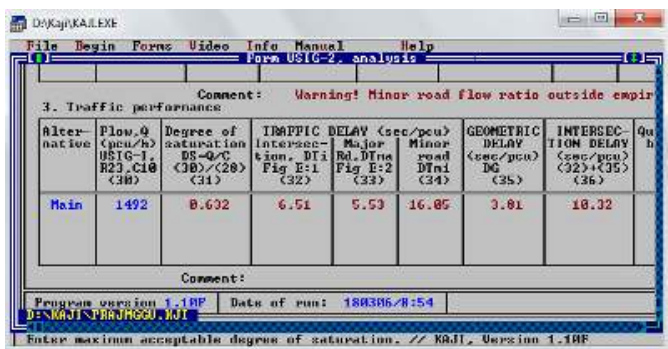

Gambar 5 Hasil kinerja eksisting simpang Jl. Prajjan - Jl. Raya Camplong pada hari libur (Minggu) Sumber: Hasil survei 2018
3. Ruas Jl. Taddan

a. Jam puncak ruas Jl. Taddan pada hari aktif dan hari libur

Berdasarkan analisis program Excel dan KAJI di bawah (Tabel 20 dan Gambar 6) mununjukan bahwa nilai derajat kejenuhan (DS) ruas Jl. Taddan pada tahun 2018 (eksisting) pada hari aktif (Rabu) adalah 0.65 (Excel) dan 0.63 (KAJI) yang berarti memiliki kinerja lalu lintas yang baik.

Tabel 20 Jam puncak pagi ruas Jl. Taddan pada hari aktif (Rabu)

\begin{tabular}{|c|c|c|c|c|}
\hline $\begin{array}{l}\text { Arus lalu } \\
\text { lintas }\end{array}$ & Derajat & Kecepatan & $\begin{array}{c}\text { Panjang segmen } \\
\text { jalan }\end{array}$ & $\begin{array}{c}\text { Waktu } \\
\text { tempuh }\end{array}$ \\
\hline & Kejenuhan & $\mathrm{V}_{\mathrm{LV}}$ & & \\
\hline (smp/jam) & (DS) & $(\mathrm{Km} / \mathrm{jam})$ & $\mathrm{L}(\mathrm{Km})$ & TT (jam) \\
\hline 1737 & 0.65 & 40 & 8.3 & 0.21 \\
\hline
\end{tabular}

Sumber: Hasil survei 2018

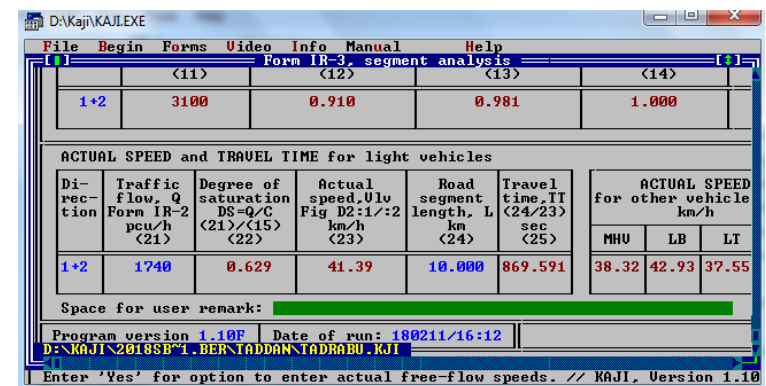

Gambar 6 Hasil kinerja eksisting ruas Jl. Taddan pada hari aktif (Rabu)

Sumber: Hasil survei 2018

Sedangkan pada hari libur (Minggu), berdasarkan analisis program Excel dan KAJI di bawah (Tabel 21 dan Gambar 7) mununjukan bahwa nilai derajat kejenuhan (DS) ruas Jl. Taddan pada tahun 2018 (eksisting) adalah 0.50 (Excel) dan 0.48 (KAJI) yang berarti memiliki kinerja lalu lintas yang baik.

Tabel 21 Jam puncak pagi ruas J1. Taddan pada hari libur (Minggu) WIB

\begin{tabular}{|c|c|c|c|c|}
\hline $\begin{array}{c}\text { Arus lalu } \\
\text { lintas } \\
\text { Q } \\
\text { (smp/jam) }\end{array}$ & $\begin{array}{l}\text { Derajat } \\
\text { Kejenuhan } \\
\text { (DS) }\end{array}$ & $\begin{array}{c}\text { Kecepatan } \\
V_{L V} \\
(\mathrm{Km} / \mathrm{jam})\end{array}$ & $\begin{array}{c}\text { Panjang segmen } \\
\text { jalan } \\
\text { L }(\mathrm{Km})\end{array}$ & $\begin{array}{l}\text { Waktu } \\
\text { tempuh } \\
\text { TT (jam) }\end{array}$ \\
\hline 1352 & 0.50 & 40 & 8.3 & 0.21 \\
\hline
\end{tabular}

Sumber: Hasil survei 2018

4). Software KAJI

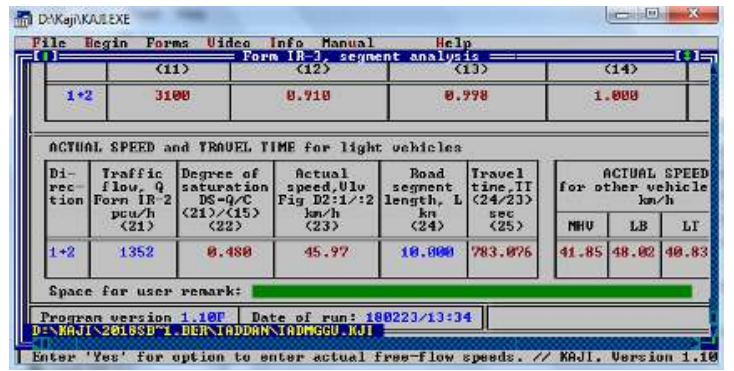

Gambar 7 Hasil kinerja eksisting ruas Jl. Taddan pada hari libur (Minggu)

Sumber: Hasil survei 2018 


\section{Volume lalu lintas setelah Pelabuhan Taddan} beroperasi pada tahun 2018

1. Volume kend/jam

a. Simpang Jl. Mutiara - Jl. Diponegoro

Tabel 22 Volume kend/jam jam puncak pagi simpang Jl. Mutiara - Jl. Diponegoro hari aktif (Rabu dan Kamis) setelah pelabuhan Taddan beroperasi 2018

\begin{tabular}{|c|c|c|c|c|c|c|c|}
\hline \multirow{2}{*}{ Hari } & \multirow{2}{*}{ Pendekat } & \multirow{2}{*}{ Arah } & \multicolumn{3}{|c|}{ Kend/jam } & \multirow{2}{*}{ Total per-arah } & \multirow{2}{*}{ Total } \\
\hline & & & LV & $\mathrm{HV}$ & $\mathrm{MC}$ & & \\
\hline \multirow{6}{*}{ Rabu } & \multirow{2}{*}{ Barat } & LT & 9 & 0 & 64 & 73 & \multirow{6}{*}{2904} \\
\hline & & $\mathrm{ST}$ & 367 & 57 & 757 & 1181 & \\
\hline & \multirow{2}{*}{ Utara } & LT & 34 & 0 & 93 & 127 & \\
\hline & & RT & 32 & 1 & 76 & 109 & \\
\hline & \multirow{2}{*}{ Timur } & RT & 32 & 0 & 88 & 121 & \\
\hline & & ST & 412 & 71 & 810 & 1293 & \\
\hline \multirow{6}{*}{ Kamis } & \multirow{2}{*}{ Barat } & $\mathrm{LT}$ & 8 & 1 & 65 & 74 & \multirow{6}{*}{2609} \\
\hline & & ST & 292 & 42 & 696 & 1030 & \\
\hline & \multirow{2}{*}{ Utara } & $\mathrm{LT}$ & 5 & 1 & 107 & 113 & \\
\hline & & RT & 17 & 1 & 83 & 101 & \\
\hline & \multirow{2}{*}{ Timur } & RT & 19 & 0 & 86 & 105 & \\
\hline & & ST & 348 & 45 & 794 & 1186 & \\
\hline
\end{tabular}

Sumber: Hasil pengolahan data

Tabel 23 Volume kend/jam jam puncak pagi simpang Jl.mutiara - Jl. Diponegoro hari libur (Sabtu dan Minggu) setelah pelabuhan Taddan beroperasi 2018

\begin{tabular}{|c|c|c|c|c|c|c|c|}
\hline \multirow{2}{*}{ Hari } & \multirow{2}{*}{ Pendekat } & \multirow{2}{*}{ Arah } & \multicolumn{3}{|c|}{ Kend/jam } & \multirow{2}{*}{$\begin{array}{l}\text { Total per- } \\
\text { arah }\end{array}$} & \multirow{2}{*}{ Total } \\
\hline & & & LV & $\mathrm{HV}$ & $\mathrm{MC}$ & & \\
\hline \multirow{6}{*}{ Sabtu } & \multirow{2}{*}{ Barat } & LT & 4 & 0 & 74 & 78 & \multirow{6}{*}{2359} \\
\hline & & ST & 253 & 70 & 611 & 934 & \\
\hline & \multirow{2}{*}{ Utara } & LT & 12 & 2 & 89 & 103 & \\
\hline & & RT & 5 & 1 & 65 & 71 & \\
\hline & \multirow{2}{*}{ Timur } & RT & 5 & 0 & 58 & 63 & \\
\hline & & ST & 252 & 83 & 775 & 1111 & \\
\hline \multirow{6}{*}{ Minggu } & \multirow{2}{*}{ Barat } & LT & 6 & 2 & 62 & 70 & \multirow{6}{*}{2407} \\
\hline & & ST & 265 & 45 & 716 & 1026 & \\
\hline & \multirow{2}{*}{ Utara } & LT & 4 & 0 & 58 & 63 & \\
\hline & & RT & 6 & 1 & 67 & 74 & \\
\hline & \multirow{2}{*}{ Timur } & $\overline{R T}$ & 5 & 0 & 59 & 64 & \\
\hline & & ST & 299 & 44 & 767 & 1110 & \\
\hline
\end{tabular}

Sumber: Hasil pengolahan data

b. Simpang Jl. Prajjan - Jl. Raya Camplong

Tabel 24 Volume kend/jam jam puncak pagi simpang Jl. Prajjan - Jl. Raya Camplong hari aktif (Rabu dan Kamis) setelah pelabuhan Taddan beroperasi 2018

\begin{tabular}{|c|c|c|c|c|c|c|c|}
\hline \multirow{2}{*}{ Hari } & \multirow{2}{*}{ Pendekat } & \multirow{2}{*}{ Arah } & \multicolumn{3}{|c|}{ Kend/jam } & \multirow{2}{*}{ Total per-arah } & \multirow{2}{*}{ Total } \\
\hline & & & LV & $\mathrm{HV}$ & $\mathrm{MC}$ & & \\
\hline \multirow{6}{*}{ Rabu } & \multirow{2}{*}{ Barat } & LT & 21 & 0 & 88 & 109 & \multirow{6}{*}{2863} \\
\hline & & ST & 440 & 57 & 763 & 1261 & \\
\hline & \multirow{2}{*}{ Utara } & LT & 32 & 2 & 57 & 91 & \\
\hline & & RT & 14 & 0 & 72 & 86 & \\
\hline & \multirow{2}{*}{ Timur } & RT & 23 & 4 & 57 & 84 & \\
\hline & & ST & 466 & 71 & 696 & 1232 & \\
\hline \multirow{6}{*}{ Kamis } & \multirow{2}{*}{ Barat } & $\mathrm{LT}$ & 9 & 0 & 87 & 96 & \multirow{6}{*}{2585} \\
\hline & & ST & 285 & 54 & 780 & 1119 & \\
\hline & \multirow{2}{*}{ Utara } & LT & 18 & 0 & 66 & 84 & \\
\hline & & RT & 15 & 1 & 85 & 101 & \\
\hline & \multirow{2}{*}{ Timur } & RT & 22 & 0 & 57 & 79 & \\
\hline & & ST & 305 & 54 & 747 & 1106 & \\
\hline
\end{tabular}

Sumber: Hasil pengolahan data
Tabel 25 Volume kend/jam jam puncak pagi simpang Jl. Prajjan - Jl. Raya Camplong hari libur (Sabtu dan Minggu) setelah pelabuhan Taddan beroperasi 2018

\begin{tabular}{|c|c|c|c|c|c|c|c|}
\hline \multirow{2}{*}{ Hari } & \multirow{2}{*}{ Pendekat } & \multirow{2}{*}{ Arah } & \multicolumn{3}{|c|}{ Kend/jam } & \multirow{2}{*}{$\begin{array}{l}\text { Total per- } \\
\text { arah }\end{array}$} & \multirow{2}{*}{ Total } \\
\hline & & & $\mathrm{LV}$ & $\mathrm{HV}$ & $\mathrm{MC}$ & & \\
\hline \multirow{6}{*}{ Sabtu } & \multirow{2}{*}{ Barat } & LT & 6 & 0 & 46 & 52 & \multirow{6}{*}{2198} \\
\hline & & ST & 280 & 82 & 615 & 977 & \\
\hline & \multirow{2}{*}{ Utara } & LT & 19 & 0 & 53 & 72 & \\
\hline & & RT & 8 & 2 & 56 & 67 & \\
\hline & \multirow{2}{*}{ Timur } & $\overline{R T}$ & 9 & 0 & 38 & 47 & \\
\hline & & ST & 277 & 71 & 635 & 983 & \\
\hline \multirow{6}{*}{ Minggu } & \multirow{2}{*}{ Barat } & LT & 15 & 5 & 80 & 100 & \multirow{6}{*}{2601} \\
\hline & & ST & 274 & 57 & 745 & 1076 & \\
\hline & \multirow{2}{*}{ Utara } & LT & 30 & 1 & 60 & 91 & \\
\hline & & RT & 10 & 1 & 165 & 176 & \\
\hline & \multirow{2}{*}{ Timur } & RT & 18 & 1 & 64 & 83 & \\
\hline & & ST & 281 & 50 & 745 & 1076 & \\
\hline
\end{tabular}

Sumber: Hasil pengolahan data

c. Ruas Jl. Taddan

Tabel 26 Volume kend/jam jam puncak pagi ruas Jl. Taddan hari aktif (Rabu dan Kamis) setelah pelabuhan Taddan beroperasi 2018

\begin{tabular}{|c|c|c|c|c|c|c|c|c|}
\hline \multirow[b]{2}{*}{ Hari } & \multirow{2}{*}{ Pendekat } & \multicolumn{5}{|c|}{ Kend/jam } & \multirow{2}{*}{$\begin{array}{l}\text { Total } \\
\text { per- } \\
\text { arah }\end{array}$} & \multirow{2}{*}{ Total } \\
\hline & & LV & MHV & LB & $\mathrm{LT}$ & $\mathrm{MC}$ & & \\
\hline \multirow{2}{*}{ Rabu } & Barat & 392 & 49 & 12 & 20 & 834 & 1307 & \multirow{2}{*}{2736} \\
\hline & Timur & 488 & 49 & 9 & 29 & 854 & 1428 & \\
\hline \multirow{2}{*}{ Kamis } & Barat & 318 & 31 & 4 & 21 & 773 & 1147 & \multirow{2}{*}{2357} \\
\hline & Timur & 349 & 32 & 11 & 23 & 795 & 1210 & \\
\hline
\end{tabular}

Sumber: Hasil pengolahan data

Tabel 27 Volume kend/jam jam puncak pagi ruas Jl. Taddan hari libur (Sabtu dan Minggu) setelah pelabuhan Taddan beroperasi 2018

\begin{tabular}{|c|c|c|c|c|c|c|c|c|}
\hline \multirow{2}{*}{ Hari } & \multirow{2}{*}{ Pendekat } & \multicolumn{5}{|c|}{ Kend/jam } & \multirow{2}{*}{$\begin{array}{l}\text { Total } \\
\text { per- } \\
\text { arah }\end{array}$} & \multirow{2}{*}{ Total } \\
\hline & & LV & MHV & LB & LT & $\mathrm{MC}$ & & \\
\hline \multirow{2}{*}{ Sabtu } & Barat & 278 & 46 & 10 & 19 & 672 & 871 & \multirow{2}{*}{1716} \\
\hline & Timur & 279 & 49 & 9 & 29 & 632 & 845 & \\
\hline \multirow{2}{*}{ Minggu } & Barat & 267 & 38 & 6 & 23 & 800 & 962 & \multirow{2}{*}{1912} \\
\hline & Timur & 271 & 32 & 11 & 17 & 818 & 950 & \\
\hline
\end{tabular}

Sumber: Hasil pengolahan data

\section{Analisis kinerja lalu lintas setelah Pelabuhan Taddan beroperasi pada tahun 2018}

1. Simpang Jl. Mutiara - Jl. Diponegoro

a. Jam puncak simpang Jl. Mutiara - Jl. Diponegoro pada hari aktif dan hari libur setelah pelabuhan Taddan beroperasi tahun 2018

Berdasarkan analisis program Excel dan KAJI di bawah (Tabel 28 dan Gambar 8) mununjukan bahwa nilai derajat kejenuhan (DS) simpang tak bersinyal Jl. Mutiara Jl. Diponegoro pada tahun 2018 setelah pelabuhan Taddan beroperasi pada hari aktif (Rabu) adalah 0.86 (Excel) dan 0.85 (KAJI) yang berarti memiliki kinerja lalu lintas yang buruk. 
Tabel 28 Jam puncak pagi simpang Jl. Mutiara - Jl. Diponegoro pada hari aktif (Rabu) setelah pelabuhan Taddan beroperasi tahun 2018

\begin{tabular}{|c|c|c|c|c|c|c|c|}
\hline $\begin{array}{c}\text { Arus } \\
\text { lalu } \\
\text { lintas } \\
\\
(\mathrm{Q}) \\
\text { smp/ja } \\
\mathrm{m} \\
\end{array}$ & $\begin{array}{c}\text { Derajat } \\
\text { Kejenuh } \\
\text { an (DS) }\end{array}$ & $\begin{array}{c}\text { Tund } \\
\text { aan } \\
\text { lalu } \\
\text { lintas } \\
\text { Simp } \\
\text { ang } \\
\end{array}$ & $\begin{array}{c}\text { Tundaa } \\
\text { n } \\
\text { lalu } \\
\text { lintas } \\
\text { Jl.Utam } \\
\text { a }\left(\mathrm{DT}_{1}\right) \\
\end{array}$ & $\begin{array}{c}\text { Tundaa } \\
\text { n } \\
\text { lalu } \\
\text { lintas } \\
\text { Jl.Mino } \\
\mathrm{r}\left(\mathrm{D}_{\mathrm{MI}}\right) \\
\end{array}$ & $\begin{array}{l}\text { Tund } \\
\text { aan } \\
\text { geom } \\
\text { etrik } \\
\text { simp } \\
\text { ang } \\
\end{array}$ & $\begin{array}{c}\text { Tunda } \\
\text { an } \\
\text { Simpa } \\
\text { ng (D) }\end{array}$ & $\begin{array}{c}\text { Peluang } \\
\text { Antrian } \\
(\mathrm{QP} \%)\end{array}$ \\
\hline 1998 & 0.86 & 10.3 & 7.54 & 44 & 3.92 & 14.25 & 58.50 \\
\hline & & & & & & & 29.61 \\
\hline
\end{tabular}

Sumber: Pengolahan data

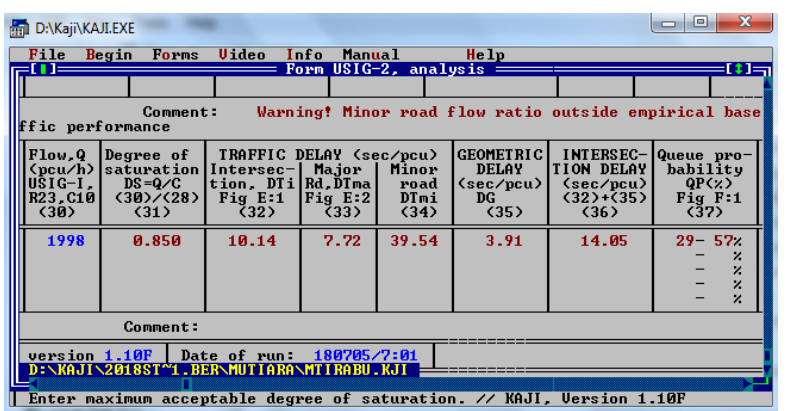

Gambar 8 Hasil kinerja simpang Jl. Mutiara - Jl.

Diponegoro pada hari aktif (Rabu) setelah pelabuhan Taddan beroperasi tahun 2018

Sumber: Pengolahan data

Sedangkan pada hari libur (Minggu), berdasarkan analisis program Excel dan KAJI di bawah (Tabel 29 dan Gambar 9) mununjukan bahwa nilai derajat kejenuhan (DS) simpang tak bersinyal Jl. Mutiara - Jl. Diponegoro pada tahun 2018 setelah pelabuhan Taddan beroperasi adalah 0.66 (Excel) dan 0.655 (KAJI) yang berarti memiliki kinerja lalu lintas yang cukup baik.

Tabel 29 Jam puncak pagi simpang Jl. Mutiara - Jl.

Diponegoro pada hari libur (Minggu) setelah pelabuhan Taddan beroperasi tahun 2018

\begin{tabular}{|c|c|c|c|c|c|c|c|c|}
\hline $\begin{array}{c}\text { Pil } \\
\text { iha } \\
\text { n }\end{array}$ & $\begin{array}{c}\text { Arus } \\
\text { lalu } \\
\text { lintas } \\
\\
\text { (Q) } \\
\text { smp/ja } \\
\mathrm{m}\end{array}$ & $\begin{array}{c}\text { Derajat } \\
\text { Kejenu } \\
\text { han } \\
\text { (DS) }\end{array}$ & $\begin{array}{c}\text { Tun } \\
\text { daan } \\
\text { lalu } \\
\text { linta } \\
\text { s } \\
\text { Sim } \\
\text { pan } \\
\text { g }\end{array}$ & $\begin{array}{c}\text { Tunda } \\
\text { an } \\
\text { lalu } \\
\text { lintas } \\
\text { Jl.Uta } \\
\text { ma } \\
\left(\mathrm{DT}_{\mathrm{l}}\right)\end{array}$ & $\begin{array}{c}\text { Tunda } \\
\text { an } \\
\text { lalu } \\
\text { lintas } \\
\text { Jl.Min } \\
\text { or } \\
\text { (D DI) }\end{array}$ & $\begin{array}{c}\text { Tun } \\
\text { daan } \\
\text { geo } \\
\text { metr } \\
\text { ik } \\
\text { simp } \\
\text { ang }\end{array}$ & $\begin{array}{l}\text { Tund } \\
\text { aan } \\
\text { Simp } \\
\text { ang } \\
\text { (D) }\end{array}$ & $\begin{array}{c}\text { Peluan } \\
\mathrm{g} \\
\text { Antria } \\
\mathrm{n} \\
(\mathrm{QP} \%)\end{array}$ \\
\hline & & & 6.8 & & & 3.7 & 10.5 & \\
\hline 1 & 1570 & 0.66 & 3 & 5.09 & 42 & 6 & 8 & 36.79 \\
\hline
\end{tabular}

Sumber: Pengolahan data

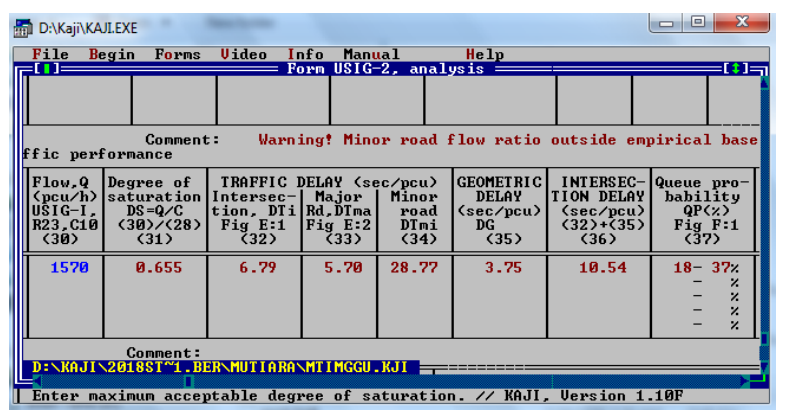

Gambar 9 Hasil kinerja simpang Jl. Mutiara - Jl.

Diponegoro pada hari libur (Minggu) setelah pelabuhan Taddan beroperasi tahun 2018

Sumber: Pengolahan data
2. Simpang Jl. Prajjan - J1. Raya Camplong

a. Jam puncak pagi simpang Jl. Prajjan - Jl. Raya Camplong pada hari aktif dan hari libur setelah pelabuhan Taddan beroperasi tahun 2018

Berdasarkan analisis program Excel dan KAJI di bawah (Tabel 30 dan Gambar 10) mununjukan bahwa nilai derajat kejenuhan (DS) simpang tak bersinyal Jl. Prajjan J1. Raya Camplong pada tahun 2018 setelah pelabuhan Taddan beroperasi pada hari aktif (Rabu) adalah 0.84 (Excel) dan 0.833 (KAJI) yang berarti memiliki kinerja lalu lintas yang buruk.

Tabel 30 Jam puncak pagi simpang Jl. Prajjan - Jl. Raya Camplong pada hari aktif (Rabu) setelah pelabuhan Taddan beroperasi tahun 2018

\begin{tabular}{|c|c|c|c|c|c|c|c|}
\hline 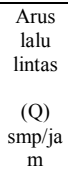 & $\begin{array}{l}\text { Derajat } \\
\text { Kejenuh } \\
\text { an (DS) }\end{array}$ & $\begin{array}{c}\text { Tund } \\
\text { aan } \\
\text { lalu } \\
\text { lintas } \\
\text { Simp } \\
\text { ang }\end{array}$ & $\begin{array}{c}\text { Tundaa } \\
n \\
\text { lalu } \\
\text { lintas } \\
\text { Jl.Utam } \\
\text { a }\left(\mathrm{DT}_{\mathrm{I}}\right)\end{array}$ & $\begin{array}{c}\text { Tundaa } \\
\mathrm{n} \\
\text { lalu } \\
\text { lintas } \\
\text { Jl.Mino } \\
\text { r (DMI) }\end{array}$ & $\begin{array}{c}\text { Tund } \\
\text { aan } \\
\text { geom } \\
\text { etrik } \\
\text { simp } \\
\text { ang }\end{array}$ & $\begin{array}{l}\text { Tunda } \\
\text { an } \\
\text { Simpa } \\
\text { ng (D) }\end{array}$ & $\begin{array}{l}\text { Peluang } \\
\text { Antrian } \\
(\mathrm{QP} \%)\end{array}$ \\
\hline 2036 & 0.84 & 9.88 & 7.23 & 55 & 3.89 & 13.78 & 55.96 \\
\hline & & & & & & & 28.28 \\
\hline
\end{tabular}

Sumber: Pengolahan data

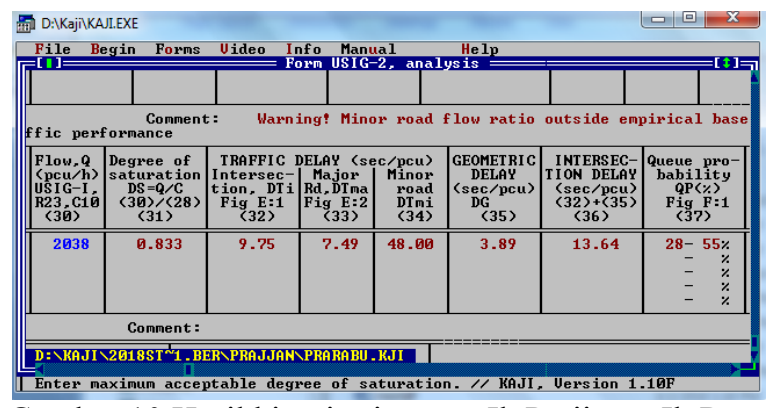

Gambar 10 Hasil kinerja simpang Jl. Prajjan - Jl. Raya

Camplong pada hari aktif (Rabu) setelah pelabuhan Taddan beroperasi tahun 2018 Sumber: Pengolahan data

Sedangkan pada hari libur (Minggu), berdasarkan analisis program Excel dan KAJI di bawah (Tabel 31 dan Gambar 11) mununjukan bahwa nilai derajat kejenuhan (DS) simpang tak bersinyal Jl. Prajjan - Jl. Raya Camplong pada tahun 2018 setelah pelabuhan Taddan beroperasi adalah 0.74 (Excel) dan 0.735 (KAJI) yang berarti memiliki kinerja lalu lintas yang cukup baik.

Tabel 31 Jam puncak pagi simpang Jl. Prajjan - Jl. Raya Camplong pada hari libur (Minggu) setelah pelabuhan Taddan beroperasi tahun 2018

\begin{tabular}{|c|c|c|c|c|c|c|c|}
\hline 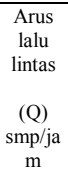 & $\begin{array}{c}\text { Derajat } \\
\text { Kejenuh } \\
\text { an (DS) }\end{array}$ & $\begin{array}{c}\text { Tund } \\
\text { aan } \\
\text { lalu } \\
\text { lintas } \\
\text { Simp } \\
\text { ang }\end{array}$ & $\begin{array}{c}\text { Tundaa } \\
n \\
\text { lalu } \\
\text { lintas } \\
\text { Jl.Utam } \\
\text { a }\left(\mathrm{DT}_{\mathrm{I}}\right)\end{array}$ & $\begin{array}{c}\text { Tundaa } \\
\mathrm{n} \\
\text { lalu } \\
\text { lintas } \\
\text { Jl.Mino } \\
\mathrm{r}\left(\mathrm{D}_{\mathrm{MI}}\right)\end{array}$ & $\begin{array}{c}\text { Tund } \\
\text { aan } \\
\text { geom } \\
\text { etrik } \\
\text { simp } \\
\text { ang }\end{array}$ & $\begin{array}{l}\text { Tunda } \\
\text { an } \\
\text { Simpa } \\
\text { ng (D) }\end{array}$ & $\begin{array}{l}\text { Peluang } \\
\text { Antrian } \\
(\mathrm{QP} \%)\end{array}$ \\
\hline 1707 & 0.74 & 7.95 & 5.89 & 29 & 3.86 & 11.81 & 44.28 \\
\hline & & & & & & & 22.02 \\
\hline
\end{tabular}

Sumber: Pengolahan data 


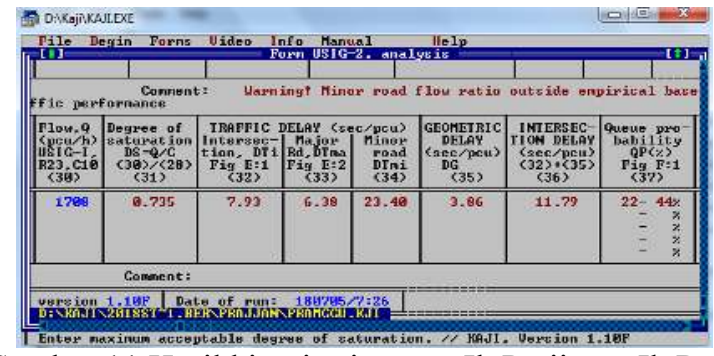

Gambar 11 Hasil kinerja simpang J1. Prajjan - Jl. Raya Camplong pada hari libur (Minggu) setelah pelabuhan

Taddan beroperasi tahun 2018

Sumber: Pengolahan data

3. Ruas Jl. Taddan

a. Jam puncak pagi ruas Jl. Taddan pada hari aktif dan hari libur setelah pelabuhan Taddan beroperasi tahun 2018

Berdasarkan analisis program Excel dan KAJI di bawah (Tabel 32 dan Gambar 12) mununjukan bahwa nilai derajat kejenuhan (DS) ruas Jl. Taddan pada tahun 2018 setelah pelabuhan Taddan beroperasi pada hari aktif (Rabu) adalah 0.75 (Excel) dan 0.721 (KAJI) yang berarti memiliki kinerja lalu lintas yang cukup baik.

Tabel 32 Jam puncak pagi ruas Jl. Taddan pada hari aktif (Rabu) setelah pelabuhan Taddan beroperasi tahun 2018

\begin{tabular}{|c|c|c|c|c|}
\hline $\begin{array}{c}\text { Arus lalu } \\
\text { lintas } \\
\text { Q } \\
\text { (smp/jam) }\end{array}$ & $\begin{array}{l}\text { Derajat } \\
\text { Kejenuhan } \\
\text { (DS) }\end{array}$ & $\begin{array}{c}\text { Kecepata } \\
n \\
V_{L V} \\
(\mathrm{Km} / \mathrm{jam})\end{array}$ & $\begin{array}{l}\text { Panjang segmen } \\
\text { jalan }\end{array}$ & $\begin{array}{l}\text { Waktu } \\
\text { tempuh }\end{array}$ \\
\hline 2005 & 0.75 & 40 & 8.3 & 0.21 \\
\hline
\end{tabular}

Sumber: Pengolahan data

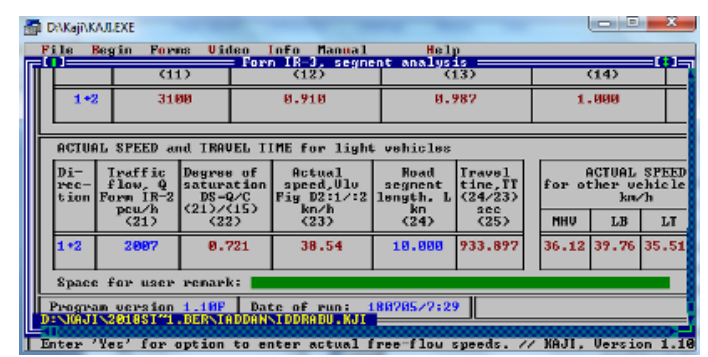

Gambar 12 Hasil kinerja ruas Jl. Taddan pada hari aktif (Rabu) setelah pelabuhan Taddan beroperasi tahun 2018 Sumber: Pengolahan data

Sedangkan pada hari libur (Minggu), berdasarkan analisis program Excel dan KAJI di bawah (Tabel 33 dan Gambar 13) mununjukan bahwa nilai derajat kejenuhan (DS) ruas Jl. Taddan pada tahun 2018 setelah pelabuhan Taddan beroperasi adalah 0.58 (Excel) dan 0.556 (KAJI) yang berarti memiliki kinerja lalu lintas yang baik.

Tabel 33 Jam puncak pagi ruas Jl. Taddan pada hari libur (Minggu) setelah pelabuhan Taddan beroperasi tahun 2018

\begin{tabular}{ccccc}
\hline $\begin{array}{c}\text { Arus lalu } \\
\text { lintas } \\
\begin{array}{c}Q \\
(\mathrm{smp} / \mathrm{jam})\end{array}\end{array}$ & $\begin{array}{c}\text { Derajat } \\
\text { Kejenuhan } \\
(\mathrm{DS})\end{array}$ & $\begin{array}{c}\text { Kecepatan } \\
\mathrm{V}_{\mathrm{LV}} \\
(\mathrm{Km} / \mathrm{jam})\end{array}$ & $\begin{array}{c}\text { Panjang segmen } \\
\text { jalan }\end{array}$ & $\begin{array}{c}\text { Waktu } \\
\text { tempuh }\end{array}$ \\
\hline 1563 & 0.58 & 40 & $\mathrm{Km})$ & TT (jam) \\
\hline
\end{tabular}

Sumber: Pengolahan data

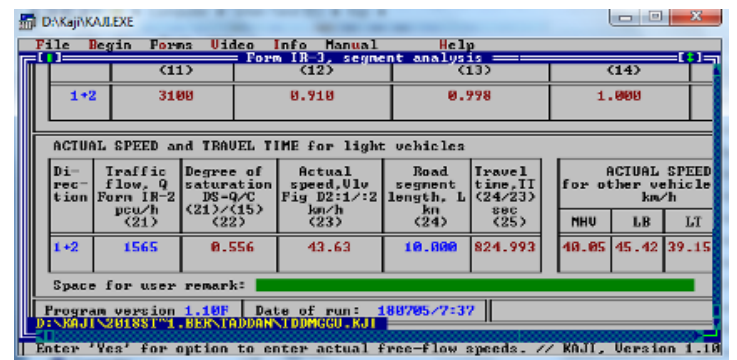

Gambar 13 Hasil kinerja ruas Jl. Taddan pada hari libur (Minggu) setelah pelabuhan Taddan beroperasi tahun 2018 Sumber: Pengolahan data

\section{KESIMPULAN DAN SARAN}

\section{Kesimpulan}

1. Pada kondisi lalu lintas eksisting (2018)

a. Simpang tak bersinyal J1. Mutiara - Jl. Diponegoro

- Nilai derajat kejenuhan (DS) simpang tak bersinyal Jl. Mutiara - Jl. Diponegoro pada hari aktif (Rabu) 0,74 yang dapat diartikan memiliki kinerja lalu lintas yang kurang cukup baik.

- Nilai derajat kejenuhan (DS) simpang tak bersinyal J1. Mutiara - Jl.Diponegoro pada hari libur (Minggu) 0,60 yang dapat diartikan memiliki kinerja lalu lintas yang baik.

b. Simpang tak bersinyal J1. Prajjan - Jl. Raya Camplong

- Nilai derajat kejenuhan (DS) simpang tak bersinyal J1. Prajjan - Jl. Raya Camplong pada hari aktif (Rabu) 0,73 yang dapat diartikan memiliki kinerja lalu lintas yang cukup baik.

- Nilai derajat kejenuhan (DS) simpang tak bersinyal Jl. Prajjan - Jl. Raya Camplong pada hari libur (Minggu) 0,64 yang dapat diartikan memiliki kinerja lalu lintas yang baik.

c. Ruas Jl. Taddan

- Nilai derajat kejenuhan (DS) ruas Jl. Taddan pada hari aktif (Rabu) 0,65 yang dapat diartikan memiliki kinerja lalu lintas yang baik.

- Nilai derajat kejenuhan (DS) ruas Jl. Taddan pada hari libur (Minggu) 0,50 yang dapat diartikan memiliki kinerja lalu lintas yang baik.

d. Survei dilakukan pada 3 januari 2018 (masuk pekan libur tahun baru)

2. Bangkitan, tarikan dan pembebanan lalu lintas

a. Bangkitan, tarikan dan pembebanan lalu lintas (smp/jam)

- Pelabuhan Taddan diprediksi membangkitkan 274 smp/jam pada hari aktif (Rabu).

- Pelabuhan Taddan membangkitkan 208 smp/jam pada hari libur (Minggu).

b. Bangkitan, tarikan dan pembebanan lalu lintas (kendaraan/jam)

- Pelabuhan Taddan pada hari aktif (Rabu) diprediksi menarik kendaraan masuk jenis LV 
sebesar 60 kendaraan; HV sebesar 12 kendaraan; dan MC sebesar 398 kendaraan serta membangkitkan kendaraan keluar jenis LV sebesar 57 kendaraan; HV sebesar 14 kendaraan; dan MC sebesar 397 kendaraan.

- Pelabuhan Taddan pada hari libur (Minggu) diprediksi menarik kendaraan masuk jenis LV sebesar 41 kendaraan; HV sebesar 3 kendaraan; dan MC sebesar 325 kendaraan serta membangkitkan kendaraan keluar jenis LV sebesar 39 kendaraan; HV sebesar 3 kendaraan; dan MC sebesar 330 kendaraan.

3. Pada kondisi lalu lintas setelah pelabuhan Taddan beroperasi (Tahun 2018)

a. Simpang tak bersinyal J1. Mutiara - Jl.Diponegoro

- Nilai derajat kejenuhan (DS) simpang tak bersinyal Jl. Mutiara - Jl.Diponegoro pada hari aktif (Rabu) 0,86 atau $\geq 0,75$ yang dapat diartikan memiliki kinerja lalu lintas yang buruk.

- Nilai derajat kejenuhan (DS) simpang tak bersinyal Jl.Mutiara-Jl.Diponegoro pada hari libur (Minggu) 0,66 atau $\leq 0,75$ yang dapat diartikan memiliki kinerja lalu lintas yang baik.

b. Simpang tak bersinyal Jl. Prajjan - Jl. Raya Camplong

- Nilai derajat kejenuhan (DS) simpang tak bersinyal Jl. Prajjan - Jl. Raya Camplong pada hari aktif (Rabu) 0,84 atau $\geq 0,75$ yang dapat diartikan memiliki kinerja lalu lintas yang buruk.

- Nilai derajat kejenuhan (DS) simpang tak bersinyal Jl. Prajjan - Jl. Raya Camplong pada hari libur (Minggu) 0,74 atau $\leq 0,75$ yang dapat diartikan memiliki kinerja lalu lintas yang cukup baik.

c. Ruas Jl. Taddan

- Nilai derajat kejenuhan (DS) ruas Jl. Taddan pada hari aktif (Rabu) 0,75 atau $=0,75$ yang dapat diartikan memiliki kinerja lalu lintas yang cukup baik.

- Nilai derajat kejenuhan (DS) ruas Jl. Taddan pada hari libur (Minggu) 0,58 atau $\leq 0,75$ yang dapat diartikan memiliki kinerja lalu lintas yang baik.

\section{Saran}

1. Saran pada kondisi setelah pelabuhan Taddan beroperasi (Tahun 2018) pada simpang sebaiknya menggunakan rekomendasi dengan pelebaran jalan mayor total 10 meter.

2. Agar penelitian selanjutnya yang sejenis, data jumlah kendaraan dan penduduk selain didapatkan dari BPS, data juga didapatkan dari dinas perhubungan untuk jumlah kendaraan dan dinas kependudukan untuk jumlah penduduk agar data lebih valid.
3. Pengambilan data lalu lintas pada penelitian ini dilakukan pada tanggal 3 januari 2018 (mendekati tahun baru) sehingga hasilnya kurang bagus. Maka, survei lalu lintas sebaiknya tidak dilakukan pada kondisi berikut:

- Hari libur aktifitas (sekolah, kerja dan sebagainya)

- Ada kegiatan tertentu

- Ada perbaikan jalan

- Hujan

\section{DAFTAR PUSTAKA}

Abidin, Z. (2016). "Studi Revitalisi Angkutan Sungai Sebagai Moda Transportasi Perkotaan di Kota Banjarmaisn". Jurnal AGREGAT, Vol. 1, No.2, November 2016, Hal 23-32, November 2016. Prodi Teknik Sipil Universitas Muhammadiyah Surabaya, Surabaya.

Direktorat Jendral Bina Marga Direktorat Bina Jalan Kota. (1997). "Manual Kapasitas Jalan Indonesia (MKJI)". Direktorat Jendral Bina Marga Direktorat Bina Jalan Kota, Jakarta.

Huda, M., dkk (2016). "Analisis Derajat Kejenuhan (DS) U-Turn dan Simpang Taman Bungkul Surabaya”. Prosiding, International Symposium of FSTPT, Universitas Islam Indonesia, Oktober, Yogyakarta.

Huda, M. (2016). "Pemodelan Trip Attraction Kendaraan Pribadi pada Rumah Makan (Studi Kasus: Jl. Mulyosari Surabaya)”. Jurnal Rekayasa Teknik Sipil, Vol. 1, No.2, November 2016, Hal 33-38, November 2016. Prodi Teknik Sipil Universitas Muhammadiyah Surabaya, Surabaya.

Huda, M. dan Muryanto, D. (2017). "Dampak Pembangunan SMPN 3 Blitar Terhadap Kinerja Lalu Lintas Sekitarnya". Jurnal AGREGAT, Vol. 2, No.1, Mei 2017, Hal 14-20, Mei 2017. Prodi Teknik Sipil Universitas Muhammadiyah Surabaya, Surabaya.

Menteri Perhubungan. (2015). "Peraturan Menteri Perhubungan Nomer 75 Tahun 2015". Menteri Perhubungan, Jakarta.

Pemerintah Indonesia. (2011). "Peraturan Pemerintah Indonesia Nomer 32 Tahun 2011". Pemerintah Indonesia, Jakarta.

Safitri, R. (2013). “Analisis Dampak Lalu Lintas Akibat Pembangunan Hartono Lisfestyle Mall di Solo Baru". Skripsi, Teknik, Teknik Sipil, Universitas Sebelas Maret, Surakarta.

Wibisono, E. (2017). “Andalalin Teluk Lamong”. Laporan tugas Andalalin. Program Studi Pasca Sarjana Teknik Sipil ITS bidang keahlian Manajemen \& Rekayasa Transportasi, Surabaya. 